This item was submitted to Loughborough's Research Repository by the author.

Items in Figshare are protected by copyright, with all rights reserved, unless otherwise indicated.

\title{
Interactively developed capabilities: Evidence from dyadic servitization relationships
}

PLEASE CITE THE PUBLISHED VERSION

http://dx.doi.org/10.1108/IJOPM-08-2015-0512

PUBLISHER

(C) Emerald

VERSION

AM (Accepted Manuscript)

\section{PUBLISHER STATEMENT}

This work is made available according to the conditions of the Creative Commons Attribution-NonCommercialNoDerivatives 4.0 International (CC BY-NC-ND 4.0) licence. Full details of this licence are available at: https://creativecommons.org/licenses/by-nc-nd/4.0/

\section{LICENCE}

CC BY-NC-ND 4.0

\section{REPOSITORY RECORD}

Raddats, Chris, Judy Zolkiewski, Vicky Story, Jamie Burton, Tim Baines, and A. Ziaee Bigdeli. 2019. "Interactively Developed Capabilities: Evidence from Dyadic Servitization Relationships". figshare. https://hdl.handle.net/2134/22179. 


\section{EEmerald $\begin{aligned} & \text { International Joumal } \\ & \text { of Operations and } \\ & \text { Production Management }\end{aligned}$}

\section{Interactively developed capabilities: Evidence from dyadic servitization relationships}

\begin{tabular}{|r|l|}
\hline Journal: & International Journal of Operations and Production Management \\
\hline Manuscript ID & IJOPM-08-2015-0512.R3 \\
\hline Manuscript Type: & Research Paper \\
\hline Keywords: & $\begin{array}{l}\text { Operational Capabilities, Servitization, Dynamic capabilities, Dyad, } \\
\text { Resources, Buyer-supplier relationships }\end{array}$ \\
\hline \multicolumn{2}{|l}{} \\
\hline
\end{tabular}




\title{
Interactively developed capabilities: \\ Evidence from dyadic servitization relationships
}

\begin{abstract}
Purpose - The paper challenges the focal firm perspective of much resource/capability research, identifying how a dyadic perspective facilitates identification of capabilities required for servitization.
\end{abstract}

Design/methodology/approach - Exploratory study consisting of seven dyadic relationships in five sectors.

Findings - An additional dimension of capabilities should be recognised; whether they are developed independently or interactively (with another actor). The following examples of interactively developed capabilities are identified: knowledge development, where partners interactively communicate to understand capabilities; service enablement, manufacturers work with suppliers and customers to support delivery of new services; service development, partners interact to optimise performance of existing services; risk management, customers work with manufacturers to manage risks of product acquisition/operation. Six propositions were developed to articulate these findings.

Research implications/limitations - Interactively developed capabilities are created when two or more actors interact to create value. Interactively developed capabilities do not just reside within one firm and, therefore, cannot be a source of competitive advantage for one firm alone. Many of the capabilities required for servitization are interactive, yet have received little research attention.

The study does not provide an exhaustive list of interactively developed capabilities, but demonstrates their existence in manufacturer/supplier and manufacturer/customer dyads.

Practical implications - Manufacturers need to understand how to develop capabilities interactively to create competitive advantage and value and identify other actors with whom these capabilities can be developed.

Originality/value - Previous research has focused on relational capabilities within a focal firm. This study extends existing theories to include interactively developed capabilities. The paper proposes that interactivity is a key dimension of actors' complementary capabilities.

Keywords: dyad; interactively developed capabilities; resources; relationships; servitization

Article classification: Research paper 


\section{Introduction}

Many manufacturers are pursuing the creation of additional value through servitization; a significant cultural shift from providing products and basic services to more complex, advanced service offerings, such as availability and capability contracting (Vandermerwe and Rada, 1988). A primary approach to analysing servitization has been through assessment of the resources and capabilities manufacturers require (Raddats et al., 2015). The ResourceBased View (RBV) (Barney, 1991) examines the need for firms to possess superior resources to achieve sustained competitive advantages. However, the applicability of the RBV has been questioned for servitizing firms since they might not own all the resources that confer competitive advantages (Kindström and Kowalkowski, 2014), suggesting other theoretical perspectives are required.

Capabilities can be conceptualised as a firm's abilities to perform productive activities (Jacobides and Winter, 2012) or produce market offerings important to customers (Madhavaram and Hunt, 2008). Consequently, capabilities to deploy resources (rather than resources per se) are the foundation of creating competitive advantages (Helfat and Winter, 2011). Capabilities are classified broadly as operational or dynamic. Operational capabilities enable a firm to conduct daily activities, such as providing existing products and services to customers; while dynamic capabilities enable firms to alter their activities to address new market opportunities (Winter, 2003). Both operational and dynamic capabilities have been used as lenses to explore how manufacturers achieve servitization (e.g., Kindström et al., 2013). 
Capability-based approaches to studying complex, interactive contexts are often criticised as having a one-sided or intra-firm perspective, as opposed to a dyadic or inter-firm perspective (Johnsen and Ford, 2006), suggesting that alone, an intra-firm perspective is insufficient to understand the capabilities required for servitization. Even a 'relational capability', the capability to interact with other companies (Lorenzoni and Lipparini, 1999; Wang et al., 2015), is still based on an intra-firm perspective. Thus, interactivity and dynamics, which are elements of the interaction and network approach (Håkansson et al., 2009), represent an alternative lens to understand resources and capabilities required for servitization (Baraldi et al., 2007).

The research gap concerns the focal-firm focus in much servitization research, both in terms of the resource/capability lenses used and empirical data collected. This is despite the prevailing view that in a business-to-business context, value is co-created by a range of actorto-actor interactions (Möller and Rajala, 2007); with interactivity central to this process. Although some studies address capabilities within dyads and networks, these are still undertaken from the perspective of the focal firm (Paiola et al., 2013). Complementary manufacturer/customer strategies and capabilities have been studied (Helander and Möller, 2007); however, this research did not consider how capabilities are developed interactively. Thus, limited attention has been paid to understanding how interactivity is reflected in the capabilities needed for servitization. Hence, this study has two objectives: 1) to explore how interactivity affects capability development within the context of servitization; 2) to provide evidence that capabilities are developed through interactions between business actors. In addressing these objectives, we answer a (largely unanswered) call by Gebauer et al. (2012) to use servitization research as a lens to contribute to capability theories, rather than vice versa. 
The paper continues with a literature review that considers resources and capabilities; manufacturers' service relationships; and capabilities within these relationships. The seven dyadic servitization cases studied highlight the importance of interactivity in the capabilities needed in both manufacturer/customer and manufacturer/supplier dyads. In the discussion, we: 1) demonstrate how interactivity is a distinct dimension of both operational and dynamic capabilities, created when two or more actors interact; 2) identify a range of interactively developed capabilities; and 3) propose that a dyadic (rather than intra-firm) perspective can reveal new insights into the capabilities for servitization. Finally, the paper presents managerial implications, limitations and areas for future research.

\section{Literature review}

\subsection{Resources and capabilities}

According to the RBV, organisations are bundles of resources, with sustained competitive advantage coming from strategies based on those resources that are valuable, rare, inimitable, and non-substitutable and best suited to their markets (Barney, 1991). Despite acknowledging the role of resources in servitization research (e.g., Raddats et al., 2016), most studies focus on capabilities (Eloranta \& Turunen, 2015); derived from the strategic configuration and active deployment of resources, rather than resources alone (Ulaga and Reinartz, 2011). Thus, our focus is capabilities.

Capabilities, an essential dimension of firm heterogeneity, are often separated into operational and dynamic, though the demarcation is often not clearly defined (Helfat and 
Winter, 2011). One approach to delineation is to conceptualise new operational capabilities as the output of dynamic capabilities (Cepeda and Vera, 2007). Dynamic capabilities are, thus, often classed as higher-level capabilities (Winter, 2003); disaggregated into: sensing (perceiving opportunities and threats); seizing (taking advantage of opportunities identified); reconfiguring (adapting a business' assets to create competitive advantages) to reflect the stages of how new market opportunities can be addressed (Teece, 2007). Within the context of servitization, dynamic capabilities are required to sense and seize new service opportunities and to reconfigure the business and exploit opportunities through development of new advanced services or solutions (Gebauer et al., 2012; Kindström et al., 2013). By virtue of being harder to replicate, dynamic capabilities are often seen as more important (than operational capabilities) for achieving sustainable competitive advantage (Helfat and Peteraf, 2003).

In contrast, operational capabilities concern existing offerings and are described as supporting 'technical fitness' (as opposed to dynamic capabilities that are seen as supporting ‘evolutionary fitness' [Teece, 2014]). A manufacturer's operational capabilities historically centre on it being an Original Equipment Manufacturer (OEM), suggesting that the firm has strong product-related technical knowledge that enables the provision of a range of productrelated offerings. Manufacturers undertaking servitization require additional capabilities beyond those centred on products (Gebauer et al., 2012). These new capabilities include having suitable service methodologies and tools (Auguste et al., 2006), an appropriate service culture (Ostrom et al., 2010), corporate leaders who are able manage the change to a more service-focused business and appropriately skilled service personnel (Raddats et al., 2015). Thus, both operational and dynamic capabilities are important for servitizing firms. Research also highlights the importance of complementarity with customers' capabilities (Helander and 
Möller, 2007), the significance of a manufacturer's network in supporting and facilitating capability development (Spring and Araujo, 2013) and mediating the link between service strategy and firm performance (Gebauer et al., 2010).

Some criticisms of resource- and capability-based theories focus on the 'myth of independence' (Gadde et al., 2003:5), with firms unable to simply deploy their own resources independently from those of other organisations, particularly since firms might not possess all the resources necessary to confer competitive advantage (Kindström and Kowalkowski, 2014). Madhavaram and Hunt's (2008) concept of 'relational' resources (i.e., establishing, developing and maintaining relationships with customers and other partners), offers insights for how firms achieve competitive advantage through their relationships with other actors. However, this approach can be criticised for taking a focal firm perspective (Johnsen and Ford, 2006). Day (2014:28) continues this critique identifying an 'inside-out myopia', whereby a firm's dynamic capabilities may be constrained by its organisational structures. Firms, therefore, need to develop greater focus on the resources and capabilities of other actors in their network (Baraldi et al., 2007) and how they might effectively combine their resources with other actors' resources. We, therefore, contend that considering capabilities without understanding how they relate to complementary capabilities (Helander and Möller, 2007) and the roles of other actors (Story et al., 2011) is problematic.

\subsection{Manufacturers' service relationships}

Firms operate within the context of interconnected business relationships, forming networks; with the ability to build and maintain relationships with other actors a key differentiator (Gadde et al., 2003). A firm's ability to create value is based on relationships with customers, 
suppliers, actors outside the firm's own industry and competitors (Ritter et al., 2004), which provide the context for the combination of internal and external activities and resources (Håkansson and Snehota, 1995).

In the context of servitization, manufacturers form service networks, with both upstream (e.g., product and service suppliers) and downstream (e.g., intermediaries and customers) actors (Finne and Holmström, 2013; Saccani et al., 2014). Relationships with these actors are critical to developing new service offerings that customers value (Windahl and Lakemond, 2006). Some work focuses on how manufacturers can create value upstream by taking over service provision for other OEMs' products (Raddats and Easingwood, 2010). However, it is the downstream environment that provides most opportunities and challenges (Ulaga and Reinartz, 2011). The delivery of advanced services to customers enables them to reduce costs and perform existing business processes more efficiently (Baines and Lightfoot, 2014). However, evidence of a servitization paradox suggests that moving into these services results in reduced profitability for the manufacturers concerned (Benedettini et al., 2015).

\subsection{Capabilities in service relationships}

Manufacturers might be unable to internally master all the capabilities required for servitization (Gebauer et al., 2013). Manufacturers' capability development, therefore, might be internal (i.e., using their own capabilities), external (i.e., using the capabilities of other actors), or mixed (i.e., using a combination of internal and external capabilities) (Paiola et al., 2013). External and mixed developments include 'indirect capabilities', whereby a manufacturer accesses the capabilities of other actors in its network (Spring and Araujo, 2014). Indeed, a number of new downstream capabilities are required by manufacturers for 
advanced services, such as the ability to price new service offerings based on risk/reward (Cova and Salle, 2008), integrate products into customer systems (Brax and Jonsson, 2009) and develop new service methodologies or processes (Paiola et al., 2013). These capabilities are generally internal to the focal firm, and even for firms adopting a mixed approach, the capabilities are generally assumed to reside within a single actor.

Alliance, partnering or relational capabilities, which enable firms to work with actors, have been discussed in general (e.g., Lorenzoni and Lipparini, 1999; Möller et al., 2005); Wang et al., 2015) and specifically in servitization research (Baines and Lightfoot, 2014; Kreye et al., 2015). For servitizing manufacturers, capabilities centred on network management/partnering and network visioning/orchestration appear most applicable (Möller et al., 2005), but further work is required to understand the interactional nature of these capabilities.

In Figure 1 we highlight the capabilities required for servitization across the different actors.

\section{Figure 1}

As manufacturers look to servitize through advanced services, the need to co-create service offerings with customers and other partners becomes imperative (Bastl et al., 2012; Brax and Jonsson, 2009). However, we are unaware of empirical research that addresses how manufacturers work interactively with other actors to develop services in the context of servitization. It is this gap that our study seeks to fill. 


\section{Methodology}

The research methodology was exploratory, designed to build theory in the area of capabilities for servitization. A case study design was adopted since it facilitates an understanding of the complexity involved in relationships (Halinen and Törnroos, 2005). The focus is on dyads, addressing capabilities that require interaction between two parties (Håkansson et al., 2009); thus, the unit of analysis is the 'dyadic relationship'. In order to establish reliability (Yin, 2014), we adopted the following procedures. Using a 'stratified' purposive sampling approach (Bryman, 2008), five manufacturers from various sectors: aerospace/defence, telecommunications, chemicals, energy and transport were sampled. The selection criteria were: large organisations (i.e., parent companies with annual turnover of over $£ 1$ billion; in the United Kingdom; undergoing servitization (evidenced by the existence of a services business unit within their structure); access to actor(s) within their network (suppliers or customers) with whom they had longstanding relationships (10+ years), with relationship duration used as a proxy for relationship success.

Senior managers from the companies' service businesses were identified. These key informants identified other individuals to interview, both within the manufacturer and customers or suppliers. Usually, we interviewed two managers from the focal manufacturer and one from the other actor. For two manufacturers (4a and 5a), there were two sets of dyads studied $(4 b / 4 c$ and $5 b / 5 c)$. Five of the dyads were manufacturer/customer and two were manufacturer/supplier, to provide a comparative perspective of the capabilities under investigation. In line with Ulaga and Reinartz (2011), we view most opportunities for capability development from servitization to be downstream and, hence, prioritised data 
collection from customer relationships. In total, 17 managers were interviewed, nine from manufacturers; eight from suppliers/customers (Table 1).

\section{Table 1}

Data were collected between 2012 and 2015 through semi-structured interviews (Saunders et al., 2007). Independent interview guides were developed for the manufacturer, customer and supplier interviews, with differences reflecting the roles each actor played (Appendix 1). Interviews were audio recorded, with each lasting, on average, one hour. Interviewees were asked to verify the transcripts before data were analysed (Bryman, 2008). Organisational data was also collected to provide evidence of service-based relationships between actors in the study, to enable triangulation with interview data (Yin, 2014). The systematic combining of data from multiple sources conforms to the abductive approach used in this study (Dubois and Gadde, 2002).

Data were analysed through thematic analysis using NVivo 10 (QSR International). Initial capability-based themes were identified within each dyad and compared to those from the other dyads to identify similarities and differences (Dubois and Araujo, 2007). Transcripts were coded independently by two researchers via detailed reading and re-reading (Crabtree and Miller, 1999). The final coding structure was reached when further analysis of all the transcripts brought forward neither new codes nor new relationships; that is, theoretical saturation was reached (Bryman, 2008).

\section{Findings}


The data suggest that companies develop both their own intra-firm capabilities and use partners to provide 'complementary' intra-firm capabilities (Helander and Möller, 2007). However, we also found strong evidence that actors cooperate to create capabilities necessary for the development and delivery of advanced services. The findings presented focus specifically on these inter-firm, interactively developed, capabilities.

\subsection{Manufacturer/supplier dyads}

Two manufacturer/supplier relationships were explored. In the first, a manufacturer of aerospace/defence equipment (1a) works with a provider of IT services (1b). The companies have an existing outsourcing contract whereby $1 \mathrm{~b}$ provides $1 \mathrm{a}$ with managed IT services. In the second, a telecommunication-products manufacturer (2a) uses a supplier (2b) to provide software and associated services that are unviable for $2 \mathrm{a}$ to develop independently.

\subsubsection{Knowledge development capabilities}

The cases highlight that even in mature relationships partners need to invest time and money to learn about each other's capabilities. This involves fully explaining the capabilities one partner possesses and how these might benefit other parties they are considering developing new services with. While data from the study show that it is possible to learn about each other's capabilities, this process is not always easy. For example, the Partner Manager in Supplier $1 \mathrm{~b}$ noted difficulties in developing appropriate relationships with counterparts in Manufacturer 1a because of his 'newness' to the relationship. Thus, learning about each other's capabilities may be impeded if good working relationships between managers do not exist. 
Even when there is awareness of the central products/services being exchanged between actors, knowledge development is vital when advanced services lie outside normal, daily partnership activities:

\author{
"So, who do we actually know who can help us as a partner... who does have \\ that capability and can bring that 'piece of the jigsaw' to provide the total \\ solution?" (Manufacturer 1a).
}

\begin{abstract}
"As you speak to more people in the business (1a) they want to know what capabilities you have. We did a presentation to the (1a's services division) Vice President who didn't know much about us other than baseline services. So, we gave a presentation about what $1 \mathrm{~b}$ does in the US on through life support. We 'blew him away' with all the attributes of where we work' (Supplier 1b).
\end{abstract}

\begin{abstract}
1a knows it has gaps in its capabilities for new advanced services, and attempts to identify potential partners that offer the missing pieces. Both parties went on to talk about how better communication of capabilities enabled $1 \mathrm{~b}$ to jointly bid with 1a for a new contract, which might have been impossible without this knowledge exchange, since neither party had the right mix of capabilities to win the bid on its own.
\end{abstract}

For $(2 \mathrm{a} / 2 \mathrm{~b})$, knowledge development formally takes place via 2a's partner managers, who manage a range of suppliers. Within $2 \mathrm{a}$, the role of partner manager was well established and designed to help understand what capabilities partners offer. This has been seen as 
necessary because $2 \mathrm{a}$ was very aware of their own limitations in developing every capability themselves:

“In this industry, we've moved more from a technical-oriented organisation into a business-oriented organisation. First of all, we wanted to create our products on our own...now we have a multitude of smaller 'boxes' and systems with a complex mesh for all these functions to be interconnected. We could not realise everything on our own; it's not possible anymore in this kind of industry" (Manufacturer 2a).

The $2 b$ interviewees recognised the importance of interactivity for developing knowledge, speaking about the informal role of 'internal champions' (including partner managers) within 2a. 2b's products were part of an established frame contract; thus, less communication was required to explain features/benefits. However, the importance of interaction with partners in building new knowledge was emphasised, both in $2 \mathrm{a}$ and $2 \mathrm{~b}$ :

"For service capability development, I would say that we really deal with the 'internal champions' within 2a. Sometimes they are located in sales, sales support, or sales development roles. We work with them in order to mobilise inside (Manufacturer 2a) and really go to market together and deliver, improve the capability. We would, of course, have to work through the champions, train them to obtain a bigger group of people inside (Manufacturer 2a) to actually be able to deliver" (Supplier 2b). 
The data suggest that this knowledge development capability needs to reside with both partners, with both sharing information for mutual benefit. Thus, $2 \mathrm{a}$ is aware of the need to build knowledge development capabilities with its partners and $2 \mathrm{~b}$ sees the best approach to doing this as being through internal champions. It is clear that this capability develops only through interaction and offers an important mechanism for knowledge development. The interviewees from $2 \mathrm{~b}$ note, however, that although their ambition is to develop and maintain a community of internal champions throughout $2 \mathrm{a}$, it is difficult to achieve in practice since these people have other roles, and conflicting priorities. They might not see themselves as advocates of $2 \mathrm{~b}$ and resist being termed internal champions. Thus, persuading these people to embrace their 'champion' role might be paramount to building a knowledge development capability and at present the interviewees from $2 \mathrm{~b}$ felt they were some way short of having the community of champions necessary to fully develop business within $2 \mathrm{a}$, suggesting the need for more interaction to achieve this.

'Knowledge development', as an ongoing, interactive activity, seems to be aligned to the dynamic capability of 'sensing' (Teece, 2007). Before these firms can 'seize' market opportunities, they should focus efforts on learning about their network partners; almost as a pre-requisite for developing other network-related capabilities. This supports the views of Helander and Möller (2007) who suggest that reducing the knowledge gap between partners is important for success. It also shows that the interaction between actors drives the development and exploitation of their capabilities. Thus, having a strong understanding of each other's capabilities through close interaction and communication is a first important step to maximising the benefits offered by complementary capabilities (Helander and Möller, 2007). 


\subsubsection{Service enablement capabilities}

This theme focuses on the interactively developed capabilities that support the introduction and viability of new services. The literature suggests that upstream partners working with manufacturers play an important role in enabling the sale and delivery of services. For manufacturer $2 \mathrm{a}, 2 \mathrm{~b}$ plays a crucial role in service enablement, particularly with products that have lower sales volumes or specialist requirements, meaning it is unwise for $2 \mathrm{a}$ to invest resources in up-skilling its own staff. From 2b's perspective, filling in gaps in 2a's portfolio is a strategic and time-consuming process; with the need to: gain acceptance (both within $2 \mathrm{~b}$ and 2a) to become part of 2a strategic initiatives; develop joint market offerings; and, realise sales of these offerings from 2a's customers. From 2a's perspective, this highlights the crucial role suppliers play in helping manufacturers to widen their market reach into what might otherwise be unprofitable markets. Interaction, thus, facilitates the development of a market-seizing capability (Teece, 2007), whereby firms exploit new market opportunities. Involvement of a partner in this process can overcome market-seizing difficulties, when markets lie outside a manufacturer's core area of expertise and knowledge (Day, 2014), but firms must recognise that the interactivity involved is a processual, time-laden activity.

Another service enablement avenue was 'Big Data' exploration and exploitation (Opresnik and Taisch, 2015). In dyad 1, the interviewees spoke about combining capabilities to enable a new aerial ground surveillance service; with 1b's data analytics capabilities combining with 1a's capabilities in operating the surveillance vehicles. Dyad 2 described such an opportunity in the context of complex telecommunications networks. This complexity means that new data analytic services are required by network operators to enable them to provide reliable and scalable services to customers: 
"Customer experience management is a new area where the operators want to 'dig out' more information about their customers, about customer behaviours, to see where customers are facing risk problems, whether they have the bandwidth they need for their services" (Manufacturer 2a).

$2 \mathrm{~b}$ supports manufacturer $2 \mathrm{a}$ through its data analytics capability in customer experience management:

\footnotetext{
"It is part of the analytics proposition. We would analyse the data that is coming from the network and provide the results back to $2 \mathrm{a}$ 's people to actually perform the work much more intelligently... and achieve better business results for the customer" (Supplier 2b).
}

\begin{abstract}
Thus, sometimes manufacturers may need to go beyond simply acquiring external capabilities from other actors via outsourcing activities, and instead interact with suppliers, aligning capabilities to seize new opportunities. Many new servitized offerings require new ways of working to deliver added value over what customers can already do for themselves and many firms are unable to achieve sufficient levels of value-add independently; needing instead to combine intra-firm capabilities to interactively create new inter-firm capabilities that are more than the sum of their parts.
\end{abstract}

\title{
4.1.3 Service development capabilities
}


This theme concerns interactive capabilities between suppliers and manufacturers for developing and delivering services to the market. In this regard, $1 \mathrm{~b}$ was able to help 1a deliver service offerings:

"We had another piece of work with 1b, we have a close relationship anyway, and they tried to operationalise our services, in terms of specific things that we needed to do" (Manufacturer 1a).

Their supplier, $1 \mathrm{~b}$, articulates its efforts to support 1a:

"1a's service organisation is all about through life support, 'cradle to the grave' type activities. We have very good capabilities in terms of consultancy as regards to supply chain, for example. So we have given them a perspective of where they are currently positioned, where they need to be and, therefore, how they could bridge that gap" (Supplier 1b).

In this capacity, $1 \mathrm{~b}$ works with $1 \mathrm{a}$ in terms of operationalising services and in helping $1 \mathrm{a}$ identify how to reposition itself. This aligns with a reconfiguration capability (Teece, 2007), since $1 \mathrm{a}$ works with $1 \mathrm{~b}$ to realign and reconfigure its business. Interactive service development capabilities are also apparent in the other dyad; since 2a's strategic focus has recently switched from services on multi-vendor products to services on its own products. This switch has been possible (while maintaining the same offerings to customers) because suppliers, such as $2 \mathrm{~b}$, have worked together with $2 \mathrm{a}$ to complete $2 \mathrm{a}$ 's service portfolio, by jointly developing a suite of services on their own products, which in the past $2 \mathrm{a}$ tried to offer to customers in-house, but are now supported by the services of $2 \mathrm{~b}$. 
Thus, evidence of interactive development of dynamic capabilities is apparent within the supplier-manufacturer dyads, which help manufacturers develop servitized offerings for new market opportunities through: knowledge development (sensing), service enablement (seizing), and service development (reconfiguring). These findings are articulated by three propositions.

Proposition 1: Collaborative knowledge development between manufacturers and suppliers enables effective market sensing.

Proposition 2: Manufacturers and suppliers seize market opportunities through interactively combining individual capabilities to enable new services to be realised. Proposition 3: Manufacturers reconfigure their businesses by interactively developing services with suppliers.

\subsection{Manufacturer/customer dyads}

Servitization literature highlights the importance of manufacturers and customers cooperating in a more coordinated fashion for advanced services, given the extent of coproduction between a supplier and customer involved in delivery of these offerings (Brax and Jonsson, 2009). Exploring these interactions, this study revealed a number of interactively-developed capabilities between manufacturers and customers that improved the management of installed products, which in turn helps customers with their own business development. We consider five dyadic manufacturer/customer relationships. Manufacturer 3a provides chemical goods and services to customer $3 \mathrm{~b}$, which is involved in water treatment. Manufacturer $4 \mathrm{a}$ supplies power-generation equipment to power generators $4 \mathrm{~b}$ and $4 \mathrm{c}$. Manufacturer 5a supplies 
vehicles to distribution and logistics providers $5 \mathrm{~b}$ and $5 \mathrm{c}$. In all cases services are increasingly being used to enhance traditional product-based relationships.

\title{
4.2.1 Service enablement capabilities
}

Service enablement within the context of manufacturer/customer dyads primarily concerns manufacturers providing finance or expertise to customers to expedite the introduction of new, technically complex offerings. 5a has evolved its customer offerings from vehicles and maintenance to fixed price service contracts and contract hire/rental contracts (which include financing) and adapted the way it works with the customer:

\begin{abstract}
"The big thing is on the finance side; $60 \%$ of what we sell we fund, so we've had to become incredibly innovative... our innovation has come from fixed price service contracts but even more importantly, fixed price contract hire and rental contracts. We've moved into the rental contract hire space, as a result of changes in the marketplace. We've had to adapt like you can't believe (Manufacturer 5a).
\end{abstract}

5a adapted its service offerings in response to customer demands and in so doing has developed new operational capabilities around product financing. From the customer's perspective, although financing is often available from banks, there can be advantages in using manufacturer-provided finance, for example:

\footnotetext{
“[Bank] is saying that we've leased this truck to you, you've paid us so much a month, you've signed these T\&Cs and all we're doing now is enforcing them. I
} 
would rather use finance through a manufacturer because he tends to be a bit more flexible with you because he wants you to buy some more trucks" (Customer 5c).

The ability to provide customers with finance under innovative terms is, therefore, an important enablement capability for winning business (5c switched to buying vehicles from 5a rather than a competitor on the basis of the financing). From the customer's perspective, the negotiation that is possible (e.g., paying per mile driven rather than acquisition of vehicles) is an important element of the contract. Thus, the interactive relational dynamics and ongoing processes in these contracts can be seen as a key differentiator for both actors.

Two contrasting perspectives on service enablement were illustrated by $4 \mathrm{a}$ and $4 \mathrm{~b}$. $4 \mathrm{a}$ focuses on developing deeper customer relationships:

\begin{abstract}
"From our point of view, the risk of substitution makes us willing partners and the contract (with $4 \mathrm{~b}$ ) provides an environment in which we can position product upgrades more successfully. So we can establish an exclusive relationship with the client now and better enable ourselves to continue that into the future through product upgrades" (Manufacturer 4a).
\end{abstract}

On the other hand, $4 \mathrm{~b}$ views interactive service enablement as an opportunity to learn about $4 \mathrm{a}$ 's products, and then seek alternative service suppliers:

\footnotetext{
"We would probably have a single tender with 4 a for the first 12 months, to understand the servicing, repair, management, condition monitoring aspects of
} 
the product. But then over this phase, we'll be transferring that into a contract that we own and have input into and probably move away from the OEM (4a) to someone we would recognise within our fleet as our main supplier" (Customer $4 b)$.

Thus, interactive service enablement is both an opportunity and risk for a manufacturer since our data suggests that customers can seek to buy products and to develop technical capabilities to manage product complexities short-term. However, customers might also look to retender service contracts to lower cost (or preferred) providers after the initial contract period expires. These capabilities are operational, with both manufacturers and customers combining resources into capabilities required to operate in the marketplace. The experiences of $4 \mathrm{a}$ and $4 \mathrm{~b}$ highlight tensions that occur as firms seek control (Zolkiewski et al., 2008). While, complementarity of resources and capabilities may facilitate the long-term survival of relationships (Lavie, 2007), firms need to balance these inter-firm efforts with their own intra-firm capability development efforts that could challenge these relationships.

\subsubsection{Service development capabilities}

The customers in this study worked with manufacturers to ensure products performed optimally, with manufacturer selection partially based on service capabilities. Customer $3 \mathrm{~b}$ used manufacturer 3a's service capabilities to co-develop and deliver its own service offerings; but required 3a to respond to technical queries to do so:

\footnotetext{
"Our mission statement is to provide the best service offering to the industry; so, for example, a technical enquiry: the technical team is tasked to respond within
} 
24 hours, even if it's to say, 'We need to research it but we'll be back to you'. But, invariably, you get an answer. So it's a very quick delivery back to the client" (Manufacturer 3a).

"3a is particularly good at providing us with technical support, so if we have difficult contaminants or just particularly unusual ones, then I know that the technical support we're going to get is going to be fast and reasonably comprehensive; whereas going elsewhere can take a matter of days instead of hours, which can be the difference between successfully tendering a project or not" (Customer 3b).

In this example, 3a worked to develop an operational capability based on speed of response, which is valued by its customer (3b) through supporting its project tender process. In addition, 3a's Marketing Manager stressed the importance of adaptability; being willing to work with $3 \mathrm{~b}$ to customise products and services in line with their customers' requirements. For example, the interviewee at $3 \mathrm{~b}$ noted how $3 \mathrm{a}$ tested the performance of its chemicals at different temperatures as part of 3b's service development activities. This enabled $3 b$ to win a contract for which chemical performance at low temperature was a key requirement.

This responsiveness to customer requirements was also apparent in the changing focus of 5a's offerings, which are no longer based on the price and technical specifications of its vehicles but their reliability, efficiency and usability from the customer's perspective:

"It's not the price of the truck but the reliability of the truck, the fuel-efficiency of the truck and the driver acceptability of the truck; these are the three big 
things. And in the servitized world that we're in now, this is what we offer" (Manufacturer 5a).

In changing its approach, 5a can now work interactively with their customers to ensure the reliability and efficiency of their offering:

\begin{abstract}
"Each vehicle is generating ( $\mathrm{X}$ thousands of) pounds of revenue per year and is operating several thousand hours per year. A vehicle is like a taxi with a meter running. If there isn't a 'passenger' in there, in other words if it's not carrying something that we're charging our clients for, we're not generating any revenue and those costs of the vehicle and the driver are all fixed costs for us" (Customer
\end{abstract} $5 b)$.

This example demonstrates how a manufacturer worked to develop a new business model, to enable them to provide more efficient and effective solutions to their customers. Thus, in both the above cases, the manufacturers' service offerings reflect the criticality of their products to customers' businesses and close interaction between the actors is essential to facilitate the development of these end-customer solutions.

\title{
4.2.3 Risk-management capabilities
}

Interactive risk management capabilities were illustrated in the energy industry by $4 \mathrm{a}$ 's relationships with its two customers, $4 \mathrm{~b}$ and $4 \mathrm{c}$. A higher degree of trust is required when a manufacturer is involved in a customer's operations, rather than simply supplying products. In this situation, customers are sharing the operational risks with the manufacturer in order to 
prevent the failure of the operation itself. Due to the criticality of power generation, trust appeared asymmetric, with $4 \mathrm{a}$ seeing an opportunity to build trust, but $4 \mathrm{c}$ seeing the dangers of over-reliance on a supplier:

"So there's a basis for the relationship which isn't present in every other part of our (product) business. That is symptomatic of a tighter coupling between the OEM in terms of that organisation being a source of parts, technology, advice and support and [the customer's] operation in terms of its ability to produce electricity" (Manufacturer 4a).

"And when you're in a contract that is the dilemma that you have then isn't it. What do they know that we don't know? On one side they could be absolutely to the line, 'this is really serious, you need to change this', or it could be this is just commercial 'I want to make more money out of you', and we don't always know where we are" (Customer 4c).

The issue of risk is particularly important for services involving technically complex products that require high availability and co-operative operation:

\footnotetext{
"The technical risks are quite high for the client, the degree of integratedness between the performance of the machine and the operation of the machine...so an operator may need the support of the technical team, the OEM" (Manufacturer 4a).
} 


\author{
"So, there is an element of cost to that but there's also a large element of the risk \\ of that asset. So, a main gas turbine; it's critical that the asset has very high \\ levels of availability. It's also not an area where we have a specialist team. So, \\ there will be a boundary at which I need that OEM support” (Customer 4b).
}

Risk management is an essential issue during servitization and this study identifies relational and technological risk that manufacturers and customers must interactively manage.

Operational services for complex, mission-critical products always represent an opportunity for manufacturers and a concern for customers, whether customers operate the products in-house or rely on an OEM or other service provider. Equally, data from the study shows that these risks extend beyond the manufacturer/customer relationship and also include risks in the customer/end customer relationship. For example, the manager in Customer $3 \mathrm{~b}$ noted the risks for its business of end customers performing operational aspects of water treatment that involve explosive gases. Thus, $3 \mathrm{~b}$ would like to get more involved in its customers' operational activities and help them to optimise operational performance and minimise risk, but cannot do so without 3a. Risk management is, therefore, likely to be influenced by risks in other relationships; thus, the development of these capabilities needs to be seen within the context of capabilities residing in other parts of the network and the integral role of interaction and trust development.

Within manufacturer/customer dyads we identify three operational capabilities in which interaction is core: service enablement, service development and risk management. These findings are articulated in three propositions. 
Proposition 4: Manufacturers and customers work collaboratively to create capabilities to enable service offerings.

Proposition 5: Manufacturers and customers develop capabilities jointly to optimise service performance.

Proposition 6: Customers manage the risk of service operations by working with manufacturers, combining manufacturers' capabilities with their own.

Table 2 sets out the interactively developed capabilities identified in this study.

Table 2

\section{Discussion}

\subsection{Theoretical implications}

The paper contributes to both servitization and capability-based research and challenges the resource/capability orthodoxy, based on the focal firm. In doing so, it answers a call from Gebauer et al. (2012) to use servitization research as a lens to contribute to operational and dynamic capability theories. It is also one of the first to consider capability development from a dyadic rather than focal firm perspective, and is noteworthy in that it includes manufacturers working with both suppliers and customers. The paper makes three main contributions.

Firstly, specifying interactively developed capabilities. Discussion about capabilities, even relational capabilities, have been criticised for largely having a one-sided, intra-firm 
focus (Johnsen and Ford, 2006; Baraldi et al., 2007). This prior work does not take into consideration interaction between actors, which is the key relational and network dynamic that facilitates access to and recombination of resources and capabilities resident in other actors. Our study extends Helander and Möller's (2007) concept of 'complementary' capabilities, by examining the interaction between actors that generate new capabilities, not just the alignment of actors' internal capabilities. Figure 2, therefore, conceptualises interactively developed capabilities at the intersection of actors' intra-firm operational and dynamic capabilities.

\section{Figure 2}

In the model, all actors are likely to have distinct, intra-firm dynamic and operational capabilities, which may be complementary to other actors' capabilities. Interactivity is, however, recognised as a separate dimension of both operational and dynamic capabilities, since some capabilities require actors to work together, but if either actor lacks this interactive dimension it is likely that the relationship will be less productive. Our data also considered the relationship between a customer and end customer (Customer $3 \mathrm{~b}$ and its customers) and how this relationship can influence the customer-manufacturer relationship. Thus, a study solely on focal dyads may be insufficient to uncover all the influences from other network actors, on particular interactively developed capabilities.

Secondly, the identification of a range of interactively developed capabilities: knowledge development, service enablement, service development, and risk management. Identification of this interactively developed aspect of capabilities reinforces the coevolvement of capabilities notion (Gebauer et al., 2012), whereby organisational learning by 
network actors drives capability development. This contrasts with the focal firm perspective often used during studies of servitization (Ulaga and Reinartz, 2011), whereby resources and capabilities are conceptualized as internal to a firm. This study begins the process of identifying areas in which co-evolvement can occur. We argue that firms adopt a mixed approach to capability development (Paiola et al., 2013), so even for services that are assumed to develop internally, in reality they form part of a broader interactive offering to customers. This aligns with extant literature (Bastl et al., 2012; Brax and Jonsson, 2009) which views co-creation of service offerings as being more important for manufacturers developing advanced services.

Thirdly, we find that capabilities are not created in isolation, even for intermediate services, such as technical support (Baines and Lightfoot, 2014). Although such services rely on a manufacturer's own products, processes and people capabilities; technical support services ultimately require additional capabilities from a customer (Helander and Möller, 2007) and, potentially, other actors. We contend that adding partnering, collaborative, or network capabilities (Lorenzoni and Lipparini, 1999; Wang et al., 2015) to other capabilities, considered internal to the manufacturer, is a complex process (supporting Ford and Håkansson [2006]). Thus, relational capability development between manufacturer and customer (Kreye et al., 2015) might involve having engineers trained to perform on-site fault diagnostics. Equally, manufacturers' customers sometimes need to include offerings that they buy from suppliers within offerings they create for their customers. We, therefore, find that interactively developed capabilities are applicable for the development of both intermediate and advanced services. 
This study suggests that an interactive approach is essential if the genuine requirements of a market are to be identified (Day, 2014). Interactive operational capabilities were apparent in manufacturer/customer dyads, with both actors cooperating to develop capabilities. In contrast, interactive dynamic capabilities appeared to be present in manufacturer/supplier dyads, with both actors adapting their capabilities to facilitate transformation of their offerings (Kindström et al., 2013). Thus, interactivity is relevant for both dynamic and operational capabilities. We contend that capabilities, dynamic or operational, should be studied through the lens of a dyad or network, since only this approach reveals the true, shared nature of the capabilities firms develop.

\subsection{Managerial implications}

Having the right capabilities for servitization provides one of the most enduring challenges for manufacturers. The findings outlined here suggest that manufacturers must rethink how these capabilities are developed. Although research encourages manufacturers to develop greater understanding of how customers use their products in an operational environment, a failure to recognise interactivity means that this does not go far enough, and manufacturers need to consider how capabilities are developed jointly with suppliers and customers. Being good at partner management or alliance development is often insufficient. Equally, actors should assess potential partners to determine whether they have sufficient relational intent (Grönroos and Helle 2010) in order to develop the necessary interactive capabilities and continue the relationship once these capabilities are developed. This is a balancing act, as once partners have acquired new capabilities through interaction they may well decide to go it alone (customer 4b). 
This study identifies four interactively developed capabilities manufacturers must cocreate with suppliers and/or customers. Knowledge development involves manufacturers and suppliers ensuring that they understand the range of capabilities each possesses. Developing capabilities jointly with suppliers is a common activity in many industries; however, existing manufacturer/supplier relationships might focus on a good or service, while other capabilities beyond this focal offering, are unknown or ignored. Service enablement concerns suppliers helping manufacturers add new service offerings into their portfolio, ones that might not be financially viable for a manufacturer to develop alone. Equally, it can concern manufacturers enabling customers to procure expensive products through service-based contracts and make more effective use of technically complex products through interactive efforts. Service development involves the joint capabilities of manufacturers and partners being turned into activities that neither party could develop or deliver on their own, thereby creating new sales opportunities. Finally, for risk management, manufacturers must understand the risks of supplier selection and product acquisition/management from a customer's perspective. Although manufacturers view services as a way to get closer to customers, closeness might signal risk to a customer who wishes to retain skills in-house, or at least not rely on one single external provider. Manufacturers need to interactively manage this risk, particularly for complex, mission-critical products, but should not assume closeness is necessarily an endpoint every customer wants.

\subsection{Limitations and future research}

The dyadic case study approach used in the study means that the findings are not transferable to other settings. We do not contend that these interactive capabilities represent an exhaustive list, nor do we propose a causal link between interactively developed capabilities and firm 
performance. Companies from other industries should be included in future studies to determine whether the four categories of interactively developed capabilities are replicable in other settings, or whether new ones emerge. Interactively developed capabilities should be tested in a confirmatory study to assess generalisability, based on the propositions developed in the study, and could be tested to determine whether they lead to improved firm performance.

The study used a small number of informants per organisation. This was in part because customer/supplier interviews were arranged via the key informant in the focal manufacturer and subsequent access to other suitably knowledgeable managers in the customer/supplier was quite difficult to achieve. Equally, we only studied 'successful' relationships; although studying failed or problematic relationships would provide valuable comparative findings. The study considers interactively developed capabilities that manufacturers form with both suppliers and customers. Although there are similarities between these groups, we recognise that these dyads may represent disparate relationships. The tenet of interactively developed capabilities applies to both dyads, but the idiosyncrasies of each are likely to be different. In future studies of resources/capabilities, within or outside the domain of servitization, we urge researchers to move beyond a focal firm perspective, as a degree of interactivity is present in nearly every capability. Thus, studies of networks or ecosystems are likely to further extend knowledge in this area. 


\section{References}

Auguste, B., Harmon, E. and Pandit, V. (2006), "The right service strategies for product companies", The McKinsey Quarterly, Vol. 1, pp. 40-51.

Baines, T. and Lightfoot, H. (2014), "Servitization of the manufacturing firm. Exploring the operations practices and technologies that deliver advanced services", International Journal of Operations Management, Vol. 34 No. 1, pp. 2-35.

Baraldi, E., Brennan, R., Harrison, D., Tunisini, A. and Zolkiewski, J. (2007), "Strategic thinking and the IMP approach: A comparative analysis", Industrial Marketing Management, Vol. 36 No. 7, pp. 879-894.

Barney, J. (1991), "Firm resources and sustained competitive advantage", Journal of Management, Vol. 17 No. 1, pp. 99-120.

Bastl, M., Johnson, M., Lightfoot, H. and Evans, S. (2012), "Buyer-supplier relationships in a servitized environment. An examination with Cannon and Perreault's framework", International Journal of Operations and Production Management, Vol. 32 No. 6, pp. $650-675$.

Benedettini, O., Swink, M. and Neely, A. (2015), "Why do servitized firms fail? A risk-based explanation", International Journal of Operations and Production Management, Vol. 35 No. 6, pp. 946 - 979.

Brax, S. and Jonsson, K. (2009), "Developing integrated solution offerings for remote diagnostics. A comparative case study of two manufacturers", International Journal of Operations and Production Management, Vol. 29 No. 5, pp. 539-560.

Bryman, A. (2008), Social Research Methods (3rd ed.), Oxford University Press, Oxford, UK.

Cepeda, G. and Vera, D. (2007), "Dynamic capabilities and operational capabilities: A knowledge management perspective", Journal of Business Research, Vol. 60 No. 5, pp. 426-437.

Cova, B. and Salle, R. (2008), "Marketing solutions in accordance with the SD logic: Cocreating value with customer network actors", Industrial Marketing Management, Vol. 37 No. 3, pp. 270-277.

Crabtree, B.F., \& Miller, W.L. (1999), "Using codes and code manuals: A template organizing style of interpretation", in Crabtree, B. \& Miller, W. (Eds.), Doing qualitative research (2nd ed.), Sage, Newbury Park, CA, pp. 163-178.

Day, G. (2014), "An outside-in approach to resource-based theories", Journal of the Academy of Marketing Science, Vol. 42 No. 1, pp. 27-28.

Dubois, A. and Araujo, L. (2007), "Case research in purchasing and supply chain management: Opportunities and challenges", Journal of Purchasing and Supply Chain Management, Vol. 13 No. 3, pp. 170-181.

Dubois, A. and Gadde, L.-E. (2002), "Systematic combining: An abductive approach to case research", Journal of Business Research, Vol. 55 No. 7, pp. 553-560.

Eloranta, V. and Turunen, T. (2015). "Seeking competitive advantage with service infusion: A systematic literature review", Journal of Service Management, Vol. 26 No. 3, pp. 394-425. 
Finne, M. and Holmström, J. (2013), “A manufacturer moving upstream: Triadic collaboration for service delivery”, Supply Chain Management: An International Journal, Vol. 18 No. 1, pp. 21-33.

Ford, D. and Håkansson, H. (2006), "IMP—Some things achieved: Much more to do", European Journal of Marketing, Vol. 40 No. 3/4, pp. 248-258

Gadde, L., Huemer, L. and Håkansson, H. (2003), "Strategizing in industrial networks", Industrial Marketing Management, Vol. 32 No. 5, pp. 357-364.

Gebauer, H., Edvardsson, B., Gustafsson, A. and Witell, L. (2010), "Match or mismatch: Strategy configurations in the service business of manufacturing companies", Journal of Service Research, Vol. 13 No. 2, pp. 198-215.

Gebauer, H., Paiola, M. and Edvardsson, B. (2012), "A capability perspective on service business development in small and medium-sized suppliers", Scandinavian Journal of Management, Vol. 28, pp. 321-339.

Gebauer, H., Paiola, M. and Saccani, N. (2013), "Characterizing service networks for moving from products to solutions", Industrial Marketing Management, Vol. 42 No. 1, pp. 3146.

Grönroos, C. and Helle, P. (2010). "Adopting a service logic in manufacturing. Conceptual foundation and metrics for mutual value creation”, Journal of Service Management, Vol. 21 No. 5, pp. 564-590.

Håkansson, H., Ford, D., Gadde, L-E., Snehota, I. and Waluszewski, A. (2009), Business in Networks, Wiley, Chichester, UK.

Håkansson, H. and Snehota, I. (1995), Developing Relationships in Business Networks, Routledge, London, England.

Halinen, A. and Törnroos, J-A. (2005), "Using case methods in the study of contemporary business networks", Journal of Business Research, Vol. 58 No. 9, pp. 1285-1297

Helander, A. and Möller, K. (2007), "System supplier's customer strategy", Industrial Marketing Management, Vol. 36 No. 6, pp. 719-730.

Helfat, C. and Peteraf, M. (2003), "The dynamic resource-based view: Capability lifecycles", Strategic Management Journal, Vol. 24, No. 10, pp. 997-1010.

Helfat, C. and Winter, S. (2011), "Untangling dynamic and operational capabilities: Strategy for the (n)ever-changing world", Strategic Management Journal, Vol. 32 No. 11, pp. $1243-1250$.

Jacobides, M. and Winter, S. (2012), “Capabilities: Structure, agency, and evolution”, Organization Science, Vol. 23 No. 5, pp. 1365-1381.

Johnsen, R.E. and Ford, D. (2006), "Interaction capability development of smaller suppliers in relationships with larger customers", Industrial Marketing Management, Vol. 35 No. 8, pp. 1002-1015.

Kindström, D. and Kowalkowski, C. (2014), "Service innovation in product-centric firms: A multinational business model perspective", Journal of Business and Industrial Marketing, Vol. 29 No. 2, pp. 96-111.

Kindström, D., Kowalkowski, C. and Sandberg, E. (2013), "Enabling service innovation: A dynamic capabilities approach", Journal of Business Research, Vol. 66 No. 8, pp. $1063-1073$. 
Kreye, M.E., Roehrich, J.K. and Lewis, M.A. (2015). "Servitizing manufacturers: The impact of service complexity and contractual and relational capabilities", Production Planning \& Control, Vol. 26 No. 14, pp. 1233-1246.

Lavie, D. (2007), "Alliance portfolios and firm performance: A study of value creation and appropriation in the U.S. software industry", Strategic Management Journal, Vol. 28 No. 12, pp. 1187-1212.

Lorenzoni, G. and Lipparini, A. (1999), "The leveraging of interfirm relationships as a distinct organizational capability: A longitudinal study”, Vol. 20 No. 4, pp. 317-338.

Madhavaram, S. and Hunt, S. (2008), "The service-dominant logic and a hierarchy of operant resources: Developing masterful operant resources and implications for marketing strategy", Journal of the Academy Of Marketing Science, Vol. 36 No. 1, pp. 67-82.

Möller, K. and Rajala, A. (2007), "Rise of strategic nets - New modes of value creation", Industrial Marketing Management, Vol. 36 No. 7, pp. 895-908.

Möller, K., Rajala, A. and Svahn, S. (2005), "Strategic business nets - Their type and management”, Journal of Business Research, Vol. 58 No. 9, pp. 1274-1284.

Opresnik, D. and Taisch, M. (2015), “The value of big data in servitization”, International Journal of Production Economics, Vol. 65, pp. 174-184.

Ostrom, A., Bitner, M., Brown, S., Burkhard, K., Goul, M., Smith-Daniels, V., Demirkan, H. and Rabinovich, E. (2010), "Moving forward and making a difference: Research priorities for the science of service", Journal of Service Research, Vol. 13 No. 1, pp. 4 36.

Paiola, M., Saccani, N., Perona, M. and Gebauer, H. (2013), "Moving from products to solutions: Strategic approaches for developing capabilities", European Management Journal, Vol. 31 No. 4, pp. 390-409.

Raddats, C., Baines, T., Burton, J., Story, V. and Zolkiewski, J. (2016), "Motivations for servitization: The impact of product complexity", International Journal of Operations and Production Management, Vol. 36 No. 5, pp. 572-591.

Raddats, C., Burton, J. and Ashman, R. (2015), "Resource configurations for services success in manufacturing companies", Journal of Service Management, Vol. 26 No. 1, pp. 97116.

Raddats, C. and Easingwood, C. (2010), "Services growth options for B2B product-centric businesses", Industrial Marketing Management, Vol. 39 No. 8, pp. 1331-1342.

Ritter, T., Wilkinson, I. and Johnston, W. (2004), "Managing in complex business networks", Industrial Marketing Management, Vol. 33 No. 3, pp. 175-183.

Saunders, M., Lewis, P. and Thornhill, A. (2007), Research Methods for Business Students (4th ed.), Pearson Education, Harlow, UK.

Saccani, N., Visintin, F. and Rapaccini, M. (2014), "Investigating the linkages between service types and supplier relationships in servitized environments", International Journal of Production Economics, Vol. 149 Iss. March, pp. 226-238.

Spring, M. and Araujo, L. (2013), "Beyond the service factory: Service innovation in manufacturing supply networks", Industrial Marketing Management, Vol. 42 No. 1, pp. 59-70. 
Spring, M. and Araujo, L. (2014), "Indirect capabilities and complex performance. Implications for procurement and operations strategy", International Journal of Operations and Production Management, Vol. 34 No. 2, pp. 150-173.

Story, V., O'Malley, L. and Hart, S. (2011), "Roles, role performance, and radical innovation competences", Industrial Marketing Management, Vol. 40 No. 6, pp. 952-966.

Teece, D. (2007), "Explicating dynamic capabilities: The nature and microfoundations of (sustainable) enterprise performance", Strategic Management Journal, Vol. 28 No. 13, pp. 1319-1350.

Teece, D. (2014), "The foundations of enterprise performance: Dynamic and ordinary capabilities in an (economic) theory of firms", Academy of Management Perspectives, Vol. 28, No. 4, pp. 328-352.

Ulaga, W. and Reinartz, W. (2011), "Hybrid offerings: How manufacturing firms combine goods and services successfully", Journal of Marketing, Vol. 75 No. 6, pp. 5-23.

Vandermerwe, S. and Rada, J. (1988), "Servitization of business: Adding value by adding services”, European Management Journal, Vol. 6, pp. 314-324.

Wang, G., Dou, W., Zhu, W and Zhou, N. (2015), “The effects of firm capabilities on external collaboration and performance: The moderating role of market turbulence", Journal of Business Research, Vol. 68 No. 9, pp. 1928-1936.

Windahl, C. and Lakemond, N. (2006), "Developing integrated solutions: The importance of relationships within the network", Industrial Marketing Management, Vol. 35 No. 7, pp. 806-818.

Winter, S. (2003), “Understanding dynamic capabilities”, Strategic Management Journal, Vol. 24 No. 10, pp. 991-995.

Yin, R. (2014), Case Study Research: Design and Methods (5th ed.), Sage, Thousand Oaks, CA.

Zolkiewski, J., Burton, J. and Stratoudaki, S. (2008), "The delicate power balance in advertising agency-client relationships: partnerships or battleground? The case of the Greek advertising market", Journal of Customer Behaviour, Vol. 7 No. 4, pp. 315-332. 


\section{Appendix 1 - Questions from interview guides}

\section{Manufacturers}

- What services do you offer to your customers?

- What capabilities does your company possess to enable the provision of services?

- Who is involved in service provision from outside your company?

- What roles do these inter-company actors play in terms of developing services?

- What service-related interactions do you have with these actors?

\section{Customers}

- What services does the focal manufacturer provide to your company?

- How do the manufacturer's services develop your businesses?

- What is your company's role in during service provision?

- Can you describe the interactions you had with the focal manufacturer during the provision of these services?

\section{Suppliers}

- What were the drivers for becoming involved with [the focal manufacturer]?

- How involved are you now - no. of projects involved with/no. of new service projects in the pipeline?

- What capabilities does your company possess to enable the provision of the manufacturer's services?

- Can you describe the interactions you had with the focal manufacturer during the provision of these services? 


\section{Figure 1: Operational and dynamic capabilities required for servitization}


Figure 2: Interactively developed capabilities within the context of dynamic and operational capabilities 


\begin{tabular}{|c|c|c|c|c|c|}
\hline $\begin{array}{l}\text { Focal manufacturer } \\
\text { (parent } \\
\text { organisation's } \\
\text { headquarters) }\end{array}$ & $\begin{array}{l}\text { Sector of focal } \\
\text { manufacturer }\end{array}$ & $\begin{array}{l}\text { Number of interviewees } \\
\text { (function) }\end{array}$ & $\begin{array}{l}\frac{\text { Other actor }(\mathrm{C}}{=\text { customer, } \mathrm{S}} \\
=\text { supplier })\end{array}$ & $\begin{array}{l}\text { Main } \\
\text { business of } \\
\text { other actor }\end{array}$ & $\begin{array}{l}\text { Number of } \\
\text { interviewees } \\
\text { (function) }\end{array}$ \\
\hline 1a (European) & Aerospace/defence & 2 (service management) & $1 b(S)$ & $\begin{array}{l}\text { Information } \\
\text { technology }\end{array}$ & 1 (partner management) \\
\hline 2a (European) & Telecommunications & 2 (service management) & $2 b(S)$ & $\begin{array}{l}\text { Software and } \\
\text { services }\end{array}$ & $\begin{array}{l}2 * \text { (partner } \\
\text { management) }\end{array}$ \\
\hline 3a (Japanese) & Chemicals & $\begin{array}{l}2 \text { (marketing/services } \\
\text { management }\end{array}$ & $3 b(C)$ & $\begin{array}{l}\text { Water } \\
\text { treatment }\end{array}$ & 1 (general management) \\
\hline \multirow[t]{2}{*}{ 4a (American) } & Energy & $\begin{array}{l}2 \text { (service management/ } \\
\text { general management) }\end{array}$ & $4 \mathrm{~b}(\mathrm{C})$ & $\begin{array}{l}\text { Power } \\
\text { generation }\end{array}$ & 1 (general management) \\
\hline & & & $4 \mathrm{c}(\mathrm{C})$ & $\begin{array}{l}\text { Power } \\
\text { generation }\end{array}$ & 1 (general management) \\
\hline \multirow[t]{2}{*}{ 5a (European) } & Transport & $\begin{array}{l}1^{* *} \text { (general } \\
\text { management) }\end{array}$ & $5 b(C)$ & $\begin{array}{l}\text { Distribution/ } \\
\text { logistics }\end{array}$ & 1 (general management) \\
\hline & & & $5 c(C)$ & $\begin{array}{l}\text { Distribution/ } \\
\text { logistics }\end{array}$ & $\begin{array}{l}1 \text { (service } \\
\text { management) }\end{array}$ \\
\hline
\end{tabular}

Table 1: Companies/interviewees who participated in the study

* All managers were interviewed separately except for those in $2 b$

** Only one manager interviewed, although the richness of the data allowed us proceed on this basis 


\begin{tabular}{|c|c|c|c|}
\hline $\begin{array}{l}\text { Capabilities built } \\
\text { through interaction }\end{array}$ & $\begin{array}{l}\text { Manufacturer/supplier dyad (dynamic } \\
\text { capabilities) }\end{array}$ & $\begin{array}{l}\text { Manufacturer/customer dyad } \\
\text { (operational capabilities) }\end{array}$ & Representative quotation \\
\hline $\begin{array}{l}\text { Knowledge } \\
\text { development }\end{array}$ & $\begin{array}{l}\text { Suppliers communicating their capabilities } \\
\text { throughout the manufacturer, sometimes } \\
\text { through 'internal champions' }\end{array}$ & No evidence in this study & $\begin{array}{l}\text { "We could not realise everything on our own; } \\
\text { it's not possible anymore in this kind of } \\
\text { industry" (Manufacturer } 2 \mathrm{a} \text { ). } \\
\text { "For service capability development, I would } \\
\text { say that we really deal with the 'internal } \\
\text { champions' within 2a" (Supplier } 2 \mathrm{~b} \text { ). }\end{array}$ \\
\hline Service enablement & $\begin{array}{l}\text { Suppliers providing manufacturers with } \\
\text { specialised services to enable new } \\
\text { customer offerings }\end{array}$ & $\begin{array}{l}\text { Manufacturer providing financial } \\
\text { solutions or technical expertise to } \\
\text { customers } \\
\text { Customers enabled to offer distinct } \\
\text { services or realign their supplier } \\
\text { strategy }\end{array}$ & $\begin{array}{l}\text { "The big thing is also on the finance side; } 60 \% \\
\text { of what we sell we fund, so we've had to } \\
\text { become incredibly innovative" } \\
\text { (Manufacturer 5a). } \\
\text { "I would rather use finance through a } \\
\text { manufacturer because he tends to be a bit } \\
\text { more flexible with you" (Customer } 5 \mathrm{c} \text { ). }\end{array}$ \\
\hline Service development & $\begin{array}{l}\text { Suppliers helping manufacturers to explore } \\
\text { new service opportunities }\end{array}$ & $\begin{array}{l}\text { Manufacturers providing the customer } \\
\text { with technical support to maximise } \\
\text { product performance } \\
\text { Customers developing market-leading } \\
\text { offerings for customers }\end{array}$ & $\begin{array}{l}\text { "We had another piece of work with } 1 \mathrm{~b} . . . \text { to } \\
\text { try and operationalise our services, in terms } \\
\text { of specific things that we needed to do" } \\
\text { (Manufacturer 1a). } \\
\text { "We have given them a perspective of where } \\
\text { they (1a) are currently positioned, where } \\
\text { they need to be and therefore how they could } \\
\text { bridge that gap" (Supplier 1b). }\end{array}$ \\
\hline Risk management & No evidence in this study & $\begin{array}{l}\text { Manufacturers managing complex } \\
\text { product operations for customers } \\
\text { Customers managing product and } \\
\text { supplier risks to ensure continuing } \\
\text { product operations }\end{array}$ & $\begin{array}{l}\text { "The technical risks are quite high for the } \\
\text { client" (Manufacturer 4a). } \\
\text { "So, there is an element of cost to that but } \\
\text { there's also a large element of the risk of that } \\
\text { asset". (Customer 4b). }\end{array}$ \\
\hline
\end{tabular}

Table 2: Interactively developed capabilities identified in the study 